\title{
MARKETING ASPECTS OF YOGHURT ENHANCED WITH TAPIOCA
}

\author{
Moga, Valentina Mădălina ${ }^{1}$ and Tița, Mihaela Adriana ${ }^{2}$ \\ 1 "Terezianum" Technological High School of Food Industry, moga.madalina25@yahoo.ro \\ 2 "Lucian Blaga" University of Sibiu, mihaela.tita@ulbsibiu.ro
}

\begin{abstract}
This research presents aspects regarding the introduction on the Romanian market of tapioca yoghurt. This product has a better texture than classic yoghurt or than yoghurt with added milk powder (the main additive used to improve the texture of the yoghurt in Romania). Tapioca is a neutral-tasting vegetable powder and it is used in many sectors of the food industry, especially as a substitute for various gelling agents, but also due to the fact that it does not contain gluten and any other known allergen. We have identified the main competitors on the yogurt market but also the potential customers. To understand the trends on the Romanian yoghurt market and consumers interest in trying the product; consumers attitude towards a new product, we used a survey. The data provided by the survey were processed to establish the SWOT Analysis of the product which is used to determine the strategic position of the product and The Elements of the Marketing Mix that are important for market growth.
\end{abstract}

KEY WORDS: tapioca, yoghurt, market research

\section{INTRODUCTION}

Milk, cheese, yoghurt and cream have been part of human nutrition for a very long time. Dairy products are rich in protein, fat, vitamins and live crops, which is why they play an essential part in our diet today.

Yoghurt is very popular among dairy products. It belongs to the category of fermented dairy products. Fermented milk has emerged as a necessity to increase the shelf life of fresh milk which is extremely perishable due to microbial action.

The manufacture of acid lactates is based on the principle of preserving milk by biochemical methods under the antiseptic action of lactic acid obtained from lactic fermentation.

According to Codex Alimentarius „Yoghurt is a coagulated milk product obtained by lactic acid fermentation through the action of Lactobacillus bulgaricus and Streptococcus thermophilus from milk and milk products (pasteurized milk or concentrated milk/ pasteurized partly skimmed milk or concentrated partly skimmed milk/pasteurized skimmed milk or concentrated skimmed milk/ pasteurized cream/ a mixture of two or more of these products), and with or without optional additions (milk powder, skimmed milk powder, unfermented buttermilk, concentrated whey, whey powder, whey proteins, whey protein concentrate, water-soluble milk proteins, edible casein, caseinates, manufactured from pasteurized products/cultures of suitable lactic acid producing bacteria in addition to of Lactobacillus bulgaricus and Streptococcus thermophilus/Sugars (in sweetened yoghurt only)). [1]

Fermented milks can be classified into four different types, depending on the type of microorganisms used for manufacturing [2] [3]:

1. products of lactic fermentation in which strains of mesophilic lactic acid bacteria are used (eg. Cultured cream, Cultured Buttermilk)
2. products of lactic fermentation with thermophilic lactic acid bacteria (yoghurt, buttermilk (bulgarian), acidophilus milk, probiotic fermented milk)

3. products obtained through alcohol-lactic fermentation (kefir, kumys)

4. products where, in addition to fermentation type (1) or (2), growth of a mold occurs (villi)

The classification of yoghurt types (Figure 1) from the market can be made according to several criteria, such as: milk raw material, which can come from several mammals (cow, goat, sheep, bufalo, etc), fat content (whole yoghurt, partially skimmed yoghurt, skimmed yoghurt), texture (set yoghurt, stirred yoghurt, drinking yoghurt, concentrate yoghurt, powder yoghurt, frozen yoghurt) and flavors (natural, fruit yoghurt, with added sweeteners and flavored with various flavors).

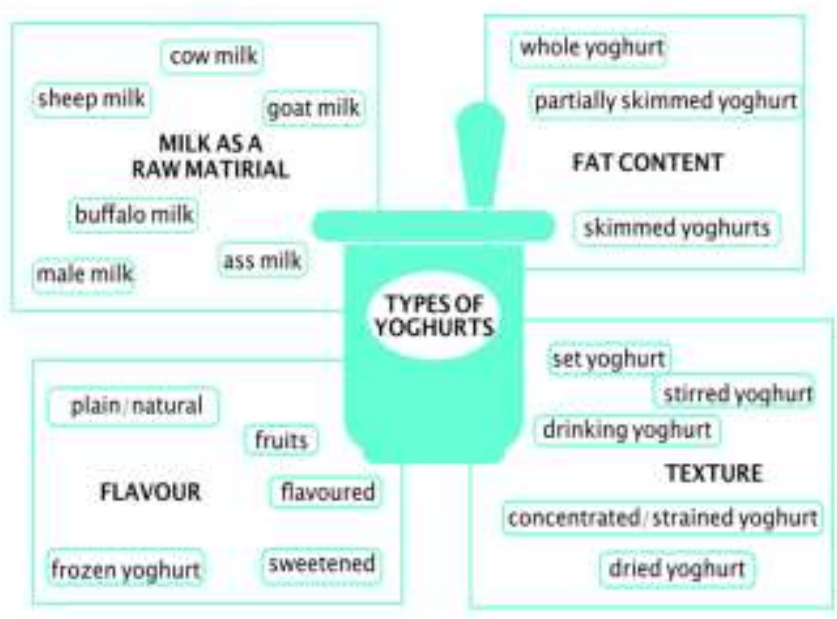

Figure 1. Yoghurt classification criteria

It is worth mentioning that there are yoghurts that contain different ingredients used to increase its functional properties. Some examples may include the use of dried fruit and 
vegetable powders as additives that contain natural sources of pectin and vitamin $\mathrm{C}$, and such yoghurts may have therapeutic effects for patients with digestive tract disorders. Other examples are probiotics, which have a lot of benefits (see chapter yoghurt and probiotics), inulin as a source of prebiotic, etc.

Over time, numerous studies have shown that the addition of certain powders to yoghurt composition, such as milk powder, whey powders, corn starch, vegetable powders and other stabilizers, improve the nutritional and functional qualities of yoghurt, but especially by using them a better quality yoghurt is obtained. This yoghurt has a more viscous and stronger curd and thus certain defects can be prevented.

Tapioca is a starch obtained by grinding the root of the Manuca plant (cultivated in South America and Africa) and is consumed mainly due to the fact that it does not contain allergens, is rich in calcium and potassium, is a source of iron, does not contain saturated fats ( does not contain cholesterol), but also because it is an easy-to-digest food.

Tapioca consumption has spread around the globe, enjoying the popularity of replacing certain thickeners, especially due to the fact that this powder does not have the ability to form gluten, so it can be easily consumed by people with the celiac disease. [4]

\section{THE SURVEY OF YOGHURT CONSUMERS EXPECTATION}

The structure of the applied survey was created according to the recommendations from the specialized literature.

It consisted of 20 questions (12 closed questions and 8 questions that offer the possibility of adding other answers than suggested), consisting of three parts:

The first part collects data about the yoghurt consumer (age; gender; occupation; origin);

The second part is intended to provide data on the consumption of yoghurt (how often yoghurt is consumed; the most commonly consumed types of yoghurt; factors that determine the choice of yoghurt type; the importance of the main characteristics of yoghurt.

The third part provides information about the specifics of the studied issue (consumers interest in trying the product; consumers attitude towards a new product; price; packaging; promotion methods).

The survey was sent for completion online to a number of 100 people from Romania. The following is centralized information about respondents:

The data were collected through the online administration of the survey. The survey was sent for completion in May 2020, to a number of 100 people from Transylvania, Romania.

\subsection{Analysis of data resulting from the application of the survey}

Information about respondents:

From the graphical figure (fig. 2) it can be observed that data collection was performed from people from both urban $(50.5 \%)$ and rural $(49.5 \%)$ environment.
Place of provenance

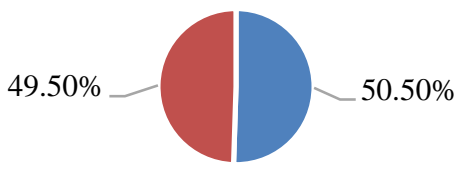

- Urban - Rural

Figure 2. Place of provenance

According to the next graphic figure (fig. 3), out of the total number of people interviewed, $63.6 \%$ are women and $36.4 \%$ are men.

Gender

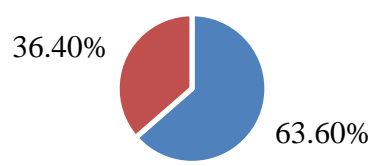

- Famale " Male

Figure 3. Gender classification of respondents

Regarding the field of activity (fig. 4), the majority are highly-qualified employees (63.6\%), followed by employees without higher education (13.1\%), students (11.1\%), pupils $(8.1 \%)$, and others such as entrepreneurs $(2 \%)$, followed by the unemployed $(1 \%)$ and retirees $(1 \%)$ in the minority.

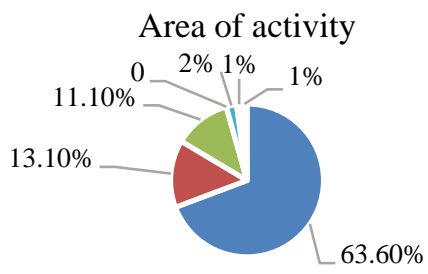

- highly-qualified employees

- Employees without higher education

- Students

- Pupils

- Others

- unemployed

Figure 4. Area of activity

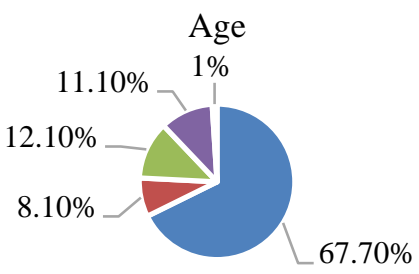

$-21-30 \mathrm{y} \quad-31-40 \mathrm{y} \quad \square 41-50 \mathrm{y} \quad-14-20 \mathrm{y}=51-60$

Figure 5. Classification of respondents by age 
As it results from the graphic figure (fig. 5), the classification by age of the persons who answered the survey can be done as follows: $67.7 \%-21-30$ years, $8.1 \%$ - 31-40 years, $12.1 \%$ 41-50 years, $11.1 \%$ - $14-20$ years, $1 \%$ - 51-60 years.

Frequency of yoghurt consumption:

Respondents to the survey reported the frequency of yoghurt consumption (Fig. 6) as follows:

- $14 \%$ consume yoghurt daily;

- $29 \%$ consume yoghurt twice a week;

- $24 \%$ consume yoghurt more than twice a week;

- $24 \%$ consume yoghurt once a month;

- $\quad 9 \%$ consume yoghurt less often than once a month.

$\begin{aligned} & \text { How often do you eat yoghurt? } \\ & \\ & \quad \text { - Daily } \\ &=\text { Twice a week } \\ &=\text { More than twice a week } \\ &=\text { Once a month } \\ &=\text { Less often than once a month. }\end{aligned}$

Figure 6. Frequency of yoghurt consumption

Regarding the preferred type of yoghurt (fig. 7), the most voted were fruit yoghurt (34\%), followed by Greek yoghurt (23\%) and natural yoghurt (18\%).

What type of yoghurt do you prefer?

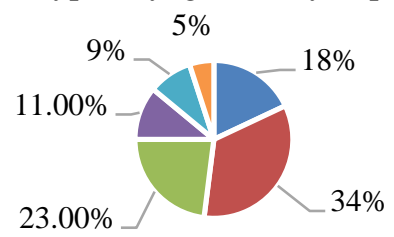

- Natural Yoghurt - Fruits Yoghurt $\quad$ Greek yoghurt

- Muesli yoghurt $\quad$ Drinking yoghurt $\backsim$ Bio Yoghurt

Figure 7. Favourite types of yoghurt

Factors that determine the choice of type of yoghurt:

When buying yoghurt (multiple choice question), respondents look for:

- $\quad$ Taste and texture $(60.2 \%)$;

- Label information: added sugar content, E content $(33.7 \%)$;

- $\quad$ Health benefits $(22.4 \%)$;

- Shelf life that should be as long as possible (19.4\%);

- $\quad$ Product price $(11.2 \%)$;

- Commercial offers (1\%);

- $\quad$ Others, such as a specific product (3.1\%);
The choice of yoghurt depends on:

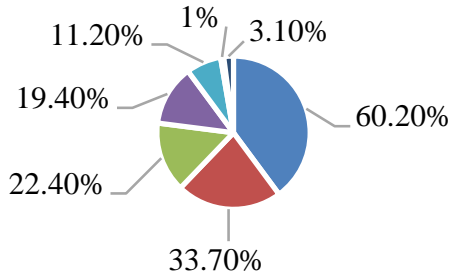

- Taste and texture

- Label information: added sugar content, E content

- Health benefits

- Shelf life that should be as long as possible

- Product price

- Commercial offers

- Others

Figure 8. Factors that determine the choice of type of yoghurt

The characteristics of yoghurt:

The benefits of yoghurt:

To the question "What are the benefits of consuming yoghurt?" (fig. 9), multiple choice question, the answers were divided as follows:

- Optimal functioning of the body: normal intestinal transit $(56.1 \%)$;

- Vitamin and calcium content (42.9\%);

- $\quad$ High protein content $(25.5 \%)$;

- $\quad$ Strengthening the immune system (12.2\%);

- Others, such as ,not consuming yoghurt for its benefits" (1\%);

What are the benefits of consuming yoghurt?

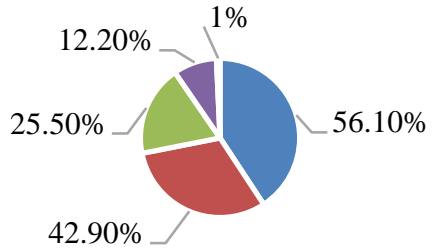

- Optimal functioning of the body: normal intestinal transit

- Vitamin and calcium content

- High protein content

- Strengthening the immune system

- Others

Figure 9. The benefits of yoghurt

Yoghurt taste:

From the graphic figure (fig. 10) it can be seen that the people who answered the survey prefer:

- $49 \%$ sour taste;

- $32 \%$ fruit taste;

- $16 \%$ sweet taste; 
- $2 \%$ vanilla/chocolate flavor.

What taste do you prefer for yoghurt?

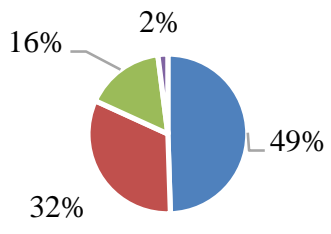

- Sour taste

Figure 10. Yoghurt taste

Yoghurt texture:

How important is the texture of yoghurt to you?

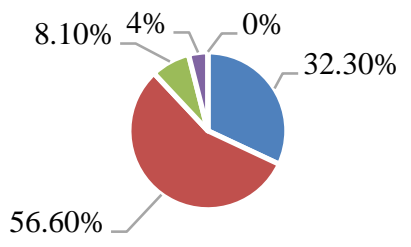

- very important - important $\quad$ neutral

Figure 11. The importance of yoghurt texture

The importance of texture can be seen from the previous graph (Fig. 11) and is considered to be a very important attribute for $32.3 \%$ of respondents, important for $56.6 \%$ of them, neutral for $8.1 \%$ and a little important for only $4 \%$ of them.

Consumption of tapioca

Have you tried products that contain tapioca?

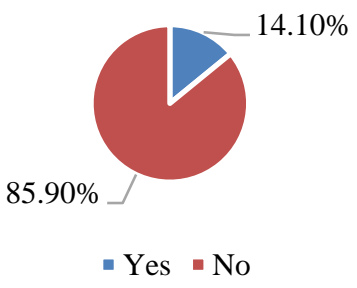

Figure 12. Consumption of tapioca

Figure 12 shows that only $18.3 \%$ of the people who answered the survey had consumed tapioca products.

However, tapioca consumption is associated with the following benefits (Fig. 13):

- Easy to digest (recommended for people with digestive disorders and irritable bowel syndrome) $(43.3 \%)$;

- Source of calcium (71 mg / $100 \mathrm{~g})$ and potassium (92 mg / $100 \mathrm{~g})(21.6 \%)$

- Does not contain allergens (20\%);

- $\quad$ Very nutritious (20\%);

- 1 in 10 people said they do not know the benefits of tapioca.
What are the benefits of eating tapioca?

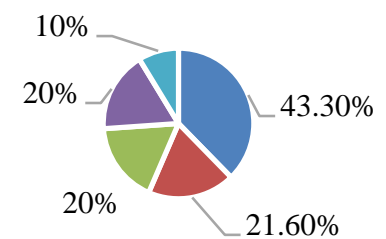

- Easy to digest (recommended for people with digestive disorders and irritable bowel syndrome)

- Source of calcium (71 mg / $100 \mathrm{~g}$ ) and potassium (92 $\mathrm{mg} / 100 \mathrm{~g})$

- Does not contain allergens

- Very nutritious

- Others

Figure 13. The benefits of the tapioca product

Yoghurt with tapioca:

Even though most respondents said that they had not consumed tapioca products (fig. 12), 90.9\% of the interviewees want to try a tapioca yoghurt (fig. 14).

Would you like to try natural cow's milk yoghurt enhanced with tapioca?

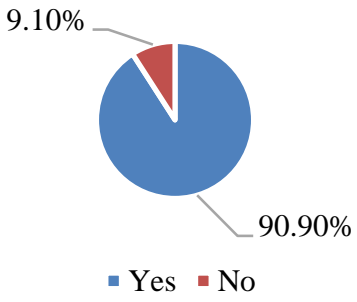

Figure 14. Yoghurt with tapioca

Yoghurt packaging:

What type of packaging do you prefer for yoghurt?

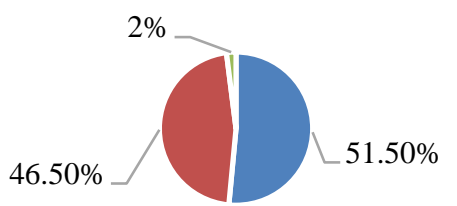

- Glass packaging - Plastic packaging " Others

Figure 15. Yoghurt packaging

From the graphic figure (fig. 15) it can be seen that $51.5 \%$ of the interviewees prefer glass packaging to the detriment of plastic packaging $(46.5 \%)$ or other packaging such as cardboard $(2 \%)$.

They consider the design of the packaging (fig. 16) as very important $10.1 \%$, important $35.4 \%$, neutral $36.4 \%$, less important $14.1 \%$ and unimportant $4 \%$. 
Is packaging design an important factor when buying yoghurt?

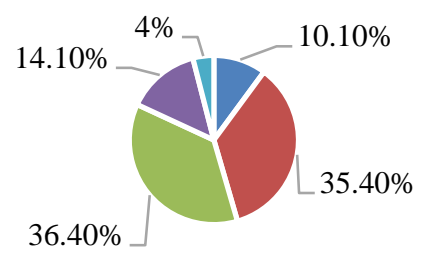

- Verry important - Important

- Neutral

- A little important - Unimportant

Figure 16. Packaging design

Regarding the classification of packaging by weight (fig.17), $56.6 \%$ of them prefer to buy yoghurt packed in $150 \mathrm{~g}$ packs, $39.4 \%$ prefer yoghurt packaged in $250 \mathrm{~g}$ packs and $4 \%$ prefer yoghurt packaged in packs of $500 \mathrm{~g}$.

What should be the weight of the yoghurt?

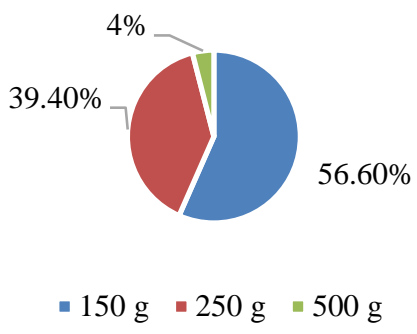

Figure 17. Yoghurt weight

Distribution of yoghurt:

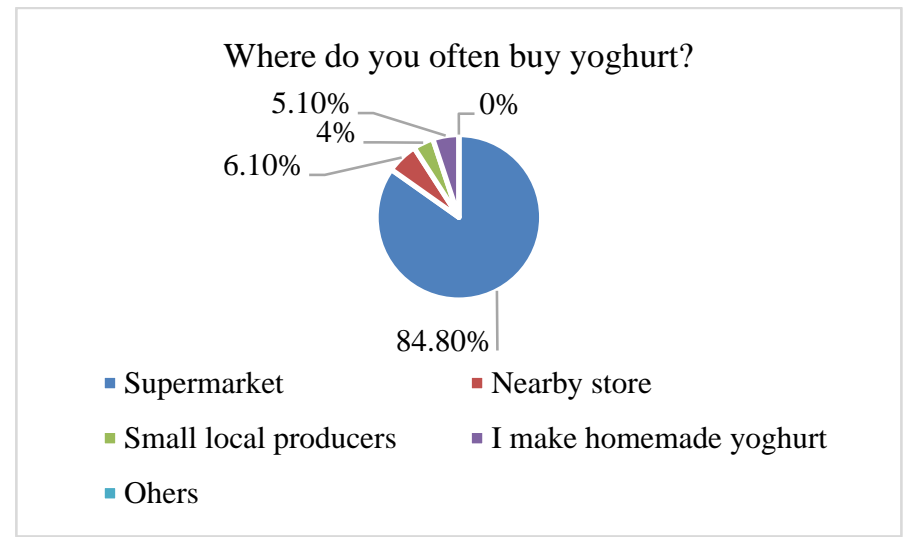

Figure 18. Distribution of yoghurt

Regarding the place where they buy yoghurt, from figure 18 it can be seen that $84.8 \%$ of respondents said they buy yoghurt from the supermarket and only $6.1 \%$ from the nearby store and $4 \%$ from small local producers and $5.1 \%$ make homemade yoghurt.

Yoghurt price:

Is price a deciding factor when buying yoghurt?
$40.40 \%$

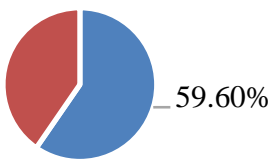

Figure 19. The importance of price

From the graphic figure (fig. 19) it can be seen that $50.6 \%$ of the respondents said that the price is not a deciding factor in choosing yoghurt.

What price would you be willing to pay for 150 $\mathrm{g}$ of yoghurt with tapioca?

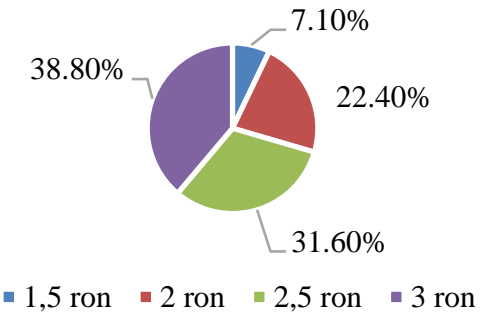

Figure 20. Price of yoghurt with tapioca

The price that the interviewees would be willing to pay for 150 grams of yoghurt with tapioca (fig.20) varies between 1.5 lei and 3 lei:

- $\quad 38.8 \%$ would be willing to pay 3 lei;

- $\quad 31.6 \%$ would be willing to pay 2.5 lei;

- $\quad 22.4 \%$ would be willing to pay 2 lei;

- $\quad 7.1 \%$ would be willing to pay 1.5 lei;

Promotion methods

The means of promotion preferred by the persons (fig questioned are presented in figure 21 and the most voted were:

- $\quad$ Promotion sales $35.1 \%$;

- $\quad$ TV advertising $29.9 \%$;

- Posts via social networks $24.7 \%$;

- $\quad$ Ads or banners $24 \%$

What kind of yoghurt promotion methods do you prefer?

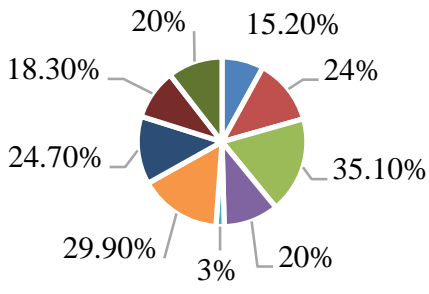

- Flyers

- Billboards

- Shelf promotions

- Gift/ contests

- Telephone contact

- TV advertising

Figure 21. Promotion methods 


\section{ASPECTS OF MARKETING RESEARCH}

\subsection{Product presentation}

Tapioca yoghurt is a yoghurt made according to the classic technology, by using cow's milk from local sources, with live crops and tapioca.

Tapioca yoghurt has a better defined texture compared to natural yoghurts, enhanced by the addition of tapioca, which increases the percentage of dry matter preventing the elimination of whey.

In Romania, most yoghurts contain milk proteins, milk powder, but also modified corn starch in order to improve the texture of classic yoghurt.

Compared to yoghurts with protein additives (milk or whey proteins) or milk powder, tapioca yoghurt has a content of lactose, saturated fats and saturated fatty acids unchanged due to the addition of tapioca powder, and the protein and lipid content remains almost unchanged. Also, tapioca increases the calcium, iron, potassium, B vitamins, omega 3 and omega 6 contents of yoghurt (100 g of tapioca contains $9 \%$ of the daily requirement of iron).

\subsection{SWOT Analyse}

SWOT analysis is an important managerial technique for understanding the strategic position of a company or a product.

The main objective of applying this method is to identify the strengths and weaknesses of tapioca yoghurt and it is desired to adapt the strengths and opportunities to reduce as much as possible the weaknesses of the product.

SWOT analysis for tapioca yoghurt:

Table 1. SWOT analysis for a tapioca yoghurt

\begin{tabular}{|c|c|}
\hline STRENGHT & WEAKNESSES \\
\hline $\begin{array}{c}\text { Natural product without } \\
\text { additives } \\
\text { Unique product on the } \\
\text { market } \\
\text { Curative effects of the } \\
\text { product (Calcium, Potassium } \\
\text { content) } \\
\text { Recyclable packaging (glass) } \\
\text { Innovative product } \\
\text { Gluten free product }\end{array}$ & $\begin{array}{l}\text { The market is loyal to a } \\
\text { variety of products belonging } \\
\text { to major brands } \\
\text { Raw material (tapioca) from } \\
\text { export } \\
\text { Unrecognized brand } \\
\text { Modern brand image, } \\
\text { acceptability difficulties for } \\
\text { traditional consumers }\end{array}$ \\
\hline OPPORTUNITIES & THREATS \\
\hline $\begin{array}{l}\text { High consumer interest in } \\
\text { natural and healthy products } \\
\text { High potential on the foreign } \\
\text { market (tapioca being a } \\
\text { product that enjoys } \\
\text { popularity) } \\
\text { The possibility of } \\
\text { diversifying the product } \\
\text { range }\end{array}$ & $\begin{array}{l}\text { Reducing dairy consumption } \\
\text { Decrease in sales prices } \\
\text { Promotional activity of } \\
\text { competing companies } \\
\text { The emergence of substitute } \\
\text { products }\end{array}$ \\
\hline
\end{tabular}

\subsection{Market research}

\subsubsection{Customers}

Yoghurt is a popular product due to the many benefits it has. It can be consumed by people of all ages.

It is known that yoghurt can be consumed even by lactose intolerant people. This is due to the low lactose content of yoghurt, but also to the fact that specific yoghurt bacteria that convert lactose from milk into lactic acid continue their activity even after ingestion. [5]

Tapioca yoghurt addresses, first of all, the market segment of informed consumers, who have difficulties in finding on the Romanian market a traditionally prepared yoghurt, little processed, without additives, which exceeds the quality of yoghurts on the market.

Tapioca yoghurt is addressed, secondly, to consumers of natural yoghurt, without the addition of fruits, cereals, cocoa, with a fat content of $3.5 \%$. Compared to this product segment, tapioca yoghurt has a firmer texture, a better bound curd, does not contain protein additives from milk, milk powder or modified starch.

\subsubsection{Competitors}

In Romania, the consumption of yoghurt is very much associated with the trust in the producer, because of this the most consumed yoghurts belong to companies that have created notoriety on the market.

International companies characterize yoghurt and sour milk products, with sales led by Danone, Albalact, Friesland Campina, Covalact and Milk Factory Brasov. The leading five players are under international ownership but operate domestic production facilities, with Albalact and Covalact owned by Lactalis Milk Factory Brasov owned by Olympus Dairy. [6]

According to a market research, The brand with the most spontaneous mentions is Danone (top of mind for $42.8 \%$ of consumers), followed by Zuzu (10\%).

The brand with the most buyers is also Danone. Interestingly, Pilos is one of the top brands with the most buyers (according to spontaneous statements) - a brand that has not benefited from TV commercials (unlike others that are lower in the rankings), but which has a good quality-price ratio and passed the confidence test for a segment of consumers. [7]

Danone, a brand owned by the French group of the same name, remained the best-selling brand in the yoghurt sector last year, a market that has grown steadily over the past five years in terms of value. In fact, the French group with the brands Danone, Activia, Cremosso and "Casa Bună" assortment has a cumulative market share of approximately $50 \%$ on the yoghurt market. In addition, Activia is the third best-selling yoghurt brand, studies show. [8]

\subsection{Elements of Marketing Mix}

\subsubsection{Product}

The product is the basic component of the marketing mix, the main means of communication of the company with the market. This represents the tangible offer of the company, which includes elements such as: quality, design, characteristics, brand strategy, packaging, related services, etc. The product strategy involves the adoption of coordinated decisions on product range, marking, packaging and labelling. [9]

Yoghurt belongs to the category of fermented dairy products.

According to Codex Alimentarius:,, Fermented Milk is a milk product obtained by fermentation of milk, which milk may have been manufactured from products obtained from milk with or without compositional modification, by the action of suitable microorganisms and resulting in reduction of $\mathrm{pH}$ with or without coagulation (iso-electric precipitation). These 
starter microorganisms shall be viable, active and abundant in the product to the date of minimum durability. If the product is heat treated after fermentation the requirement for viable microorganisms does not apply. [10]

Consumers interest in healthy products with transparent ingredients and preparation, as well as the desire to find products with no additives and allergens on the market, has grown more and more every year. It is known that a balanced diet is essential to prevent disease.

According to the survey, yoghurt consumers associate yoghurt with the health benefits it brings, such as the normal functioning of the intestinal transit, the content of vitamins and calcium and the high protein content. In terms of product features, consumers are interested in taste and texture, most prefer the authentic, classic-sour taste. Another important aspect regarding the choice of yoghurt by the consumer is the information that the product has on the label, namely, consumers are looking for products that do not contain additives or added sugar.

Tapioca yoghurt is a product with a classic-sour taste and well-defined texture (due to the content of tapioca), of specific white colour, obtained through the classic process of obtaining yoghurt, without the addition of stabilizers and flavor enhancers. It enjoys a high calcium content, coming from both milk and tapioca and it does not contain gluten.

\subsubsection{Price}

Price is one of the most important variables of the marketing mix; it influences the volume and value of sales, market share, and the company's profit. The price decision has immediate effect: the price can be changed quickly, while it takes several months even years to organize, for example, an advertising campaign, to develop a new product or to create a distribution network. [9]

The price of the finished product varies depending on many factors. However, for the calculation of the price of the product, the following are taken into account:

- $\quad$ The price of the raw material;

- Production costs;

- Competitive prices;

- Demand and supply.

We asked the answers to the survey "What would be the price they are willing to pay for $150 \mathrm{~g}$ of tapioca yoghurt?". They replied that they are willing to pay between 2 and 3 lei for tapioca yoghurt.

They replied that they are willing to pay between 2 and 3 lei for tapioca yoghurt. This is a normal price because the prices of yoghurt in Romania vary between 1 lei and 3 lei for the assortments of products packaged in plastic packaging with weights between 130-150 g, there are variations depending on the brand and assortment. The price can exceed 4 lei for products packaged in glass with quantities over $200 \mathrm{~g}$, also considered premium products.

Experiments have shown that, in most cases, buyers tend to associate a negative image with low-priced products and a positive image with high-priced products; when the uncertainty between several brands is high, the consumer tends to reduce it by attributing the best quality to the product that displays the highest price. Speculated by traders, this situation is known in marketing as the quality effect. [9]
But not always, when a company sells expensive products, their price is also quality. In the case of food, the ingredients, their role and their functionality for the human body must be considered by the consumer.

\subsubsection{Promotion}

An element of the marketing mix, promotion is seen as a way to gain new customers, information and persuasion; it is essential for the company to make known and remind current and potential customers the advantages that its products and services offer (benefits such as product quality, an attractive price, warranty, after-sales services, etc.). To achieve maximum communication impact, the promotional mix must be effectively synchronized with all components of the marketing mix. [9]

The means of promotion have varied more and more, and companies pay huge sums for this. Today we see advertisements everywhere: on TV, in the store, on the street, we receive them by e-mail or by messages on our mobile phone or on social networks, in the mail or when we open certain web pages.

According to the survey applied, respondents prefer sales promotions. In general, for yoghurt, in Romania the discounts of type $4+2$ are applied (you buy 4 you get 6 ).

According to Frone [9], specific promotional communication tools are integrated into the promotional mix (also known as the marketing communications mix). The promotional mix includes a multitude of communication and promotion tools, the main categories being:

- $\quad$ advertising (publicity) media;

- $\quad$ sales promotion (promotions);

- merchandising;

- direct advertising, telemarketing;

- public relations - PR.

Design \& graphics. Promotion through packaging

In addition to the function of preserving and protecting food, the function of handling, storage and transport or the function of informing the consumer, the packaging is meant to attract and convince consumers, a function that plays an important role, being closely correlated with other functions.

In order to fulfil this role, the packaging must provide as complete information as possible on the product in question, helping to increase the feeling of confidence in the quality offered by the manufacturer. An aesthetic packaging that is the bearer of useful information about the product (characteristics, mode of use, shelf life, etc.) attracts the attention of buyers and favors the purchase decision. [11]

The promotional action consisting in using the packaging as a determining factor in promoting the image of a product especially the luxury ones. The packaging technology, the printing techniques, the design, the variety of materials used allowed the development of communication through packaging. In the food field, the influence of packaging on consumers' perception of product quality is decisive. [12]

According to Law 88/2016 [13] and Law 192/2017 (Romanian Parliament, 2017), the label for dairy products must contain the following:

- $\quad$ name of the food product; 
- $\quad$ list of ingredients used;

- product weight;

- expiration date;

- $\quad$ special storage conditions and/or conditions of use;

- country of origin or place of provenance of the milk with the largest share;

- $\quad$ name of the packer and the identification mark;

name of the milk processing economic operator;

nutrition declaration;

- fat content expressed as a percentage;

the heat treatment process used;

- for milk and milk products derived from animal species other than cows, the species from which milk is derived must be specified.

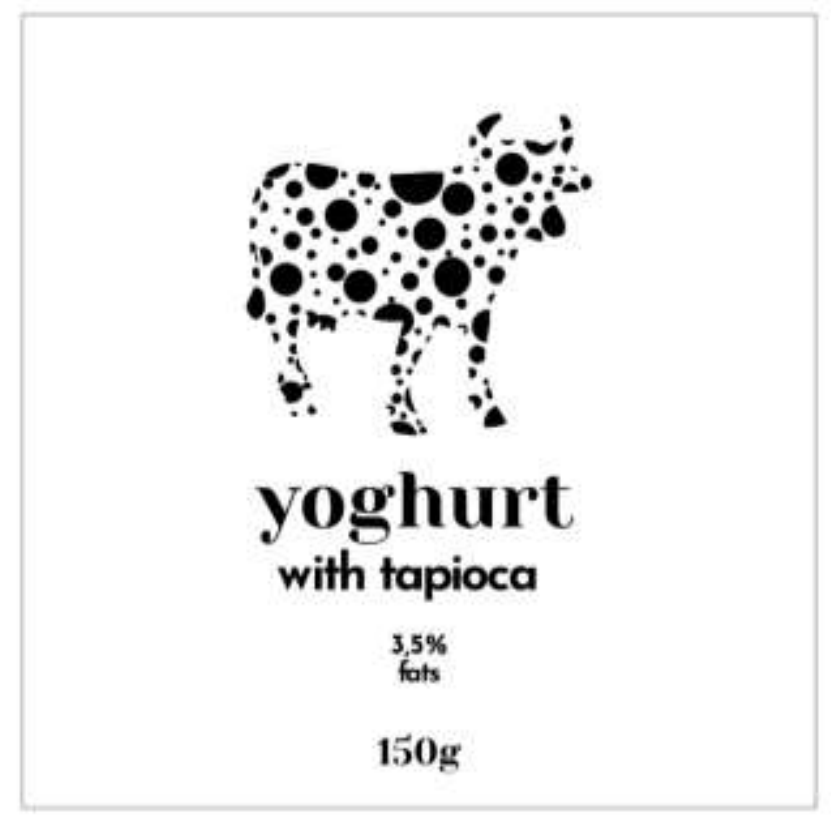

- changes in composition must be specified on the label: enrichment of milk with milk proteins, mineral salts and vitamins.

The conditions for additional information to be entered in the field of view are:

- The term „natural product” may only used by processors using $100 \%$ as raw material milk from cows, buffaloes, sheep and goats and natural components derived strictly from milk, without the composition of products of vegetable or animal origin other than milk;

- The „Product of Romania” inscription on the label may be used only by processors using $100 \%$ Romanian-origin milk with traceability documents.

The packaging design (fig. 22) was made using the graphics application, Affinity Designer. The black color of the font compared to the white color of yoghurt, expresses elegance.

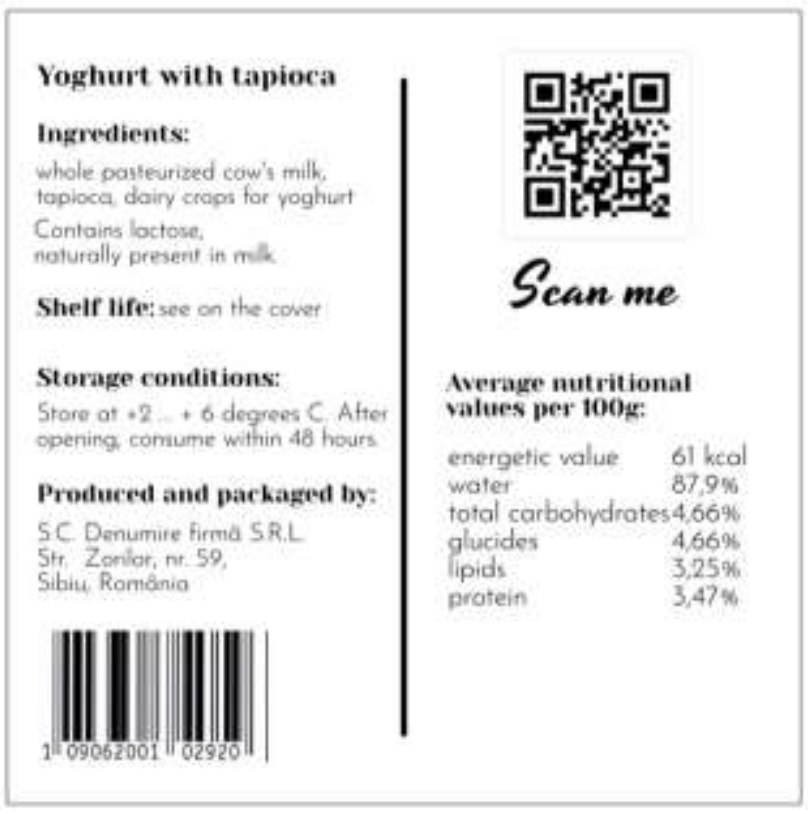

Figure 22. Packaging model, own archive

\subsubsection{Placement}

A distribution circuit is the route taken by a product from the manufacturer to the final consumer. It usually consists of one or more distribution channels (a category of intermediaries, having the same nature and the same specialization, which participates in the flow of the product from the producer to the consumer/end user). [9]

The distribution of the product can be done through direct sales (from direct producer to consumer) and through indirect sales (through intermediaries. In the case of yoghurt, as in the case of other foods, indirect sales are practiced.

In Romania, yoghurt sales are carried out through chain stores:

- Neighborhood stores;

- Grocery stores;

- Supermarkets.

According to the survey applied, yoghurt consumers are familiar with this mode of distribution (87.7\% said they buy yoghurt from the supermarket).

\section{CONCLUSIONS}

Following the market research we can submit that the consumption of yoghurt is most often associated with the optimal functioning of the digestive system and the content of calcium and vitamins of the yoghurt.

The answers to the survey show that most respondents $(90.90 \%)$ are interested in trying a new product, tapioca yoghurt, even if few of them have tried products containing tapioca and even if it is believed about Romanian consumers that they are traditionalists and slightly open to the new.

Also, the answers to the survey show that the choice of yoghurt depends very much on the taste and texture of the yoghurt. The sour taste (or classic taste) of yogurt is preferred by almost half of the respondents $(49 \%)$, followed by the fruit taste $(32 \%)$. The texture of yoghurt is important $(52.2 \%)$ and very important $(32.3 \%)$ for the consumers surveyed, and the rest of them consider the texture as a neutral attribute $(8.1 \%)$ or only slightly important $(4 \%)$.

Following the analysis, we believe that the addition of tapioca to yogurt could be promising. 


\section{REFERENCES}

1. Codex Alimentarius. (1975). CODEX STANDARD FOR YOGHURT (YOGURT) AND SWEETENED YOGHURT (SWEETENED YOGURT).

2. Surono, I. S., \& Hosono, A. (2011). FERMENTED MILKS. Types and Standards of Identity. In Encyclopedia of Dairy Sciences, Second Edition (Vol. 2, pp. 470-476. Elsevier.

3. Walstra, P., Wouters, J. T., \& Geurts, T. J. (2006). Dairy Science and Technology. Taylor \& Francis.

4. Breuninger, W. F., Piyachomkwan, K., \& Sriroth, K. (2009, 12). Tapioca/Cassava Starch. Retrieved 04 2020, from Researchgate: https://www.researchgate.net/publication/279433516_Ta piocaCassava_Starch

5. EFSA. (2011, 1 12). Scientific Opinion on the substantiation of health claims related to live yoghurt cultures and improved lactose digestion (ID 1143, 2976) pursuant to Article 13(1) of Regulation (EC) No 1924/20061. Retrieved 04 2020, from efsa.onlinelibrary.wildey.com: https://efsa.onlinelibrary.wiley.com/doi/pdf/10.2903/j.efs a.2010.1763

6. Euromonitor International. $(2019,11)$. Yoghurt and Sour Milk Products in Romania. Retrieved 05 2020, from Euromonitor International: https://www.euromonitor.com/yoghurt-and-sour-milkproducts-in-romania/report
7. Millward Brown. (2019). Consumul de iaurt. Retrieved 05 2020, from Revistaprogresiv.ro: https://revistaprogresiv.ro/sites/default/files/resources/file s/studiu_iaurt_millwardbrown.pdf

8. Millward Brown. (2019). Consumption of yogurt. Retrieved 05 2020, from revistaprogresiv.ro: https://revistaprogresiv.ro/sites/default/files/resources/file s/studiu_iaurt_millwardbrown.pdf

9. Frone, D. (2012). Marketing. The basics of marketing. Course support. București.

10. Codex Alimentarius. (2010). CODEX STANDARD FOR FERMENTED MILKS CODEX STAN 243-2003.

11. Moldovan, N., \& Ștețca, G. (2012). Food promotion function. Retrieved 05 2020, from USAMV Cluj: http://www.usamvcluj.ro/simpo_stud/files/2012/1.Facult atea $\% 20 \mathrm{de} \% 20$ Agricultura/03.Stiinta\%20si\%20tehnologi a\%20alimentelor/MOLDOVAN\%20NATASA.pdf

12. IQads. (2020). Promotion by packaging. Retrieved 05 2020, from IQads: https://www.iqads.ro/dictionar/promovare-prin-ambalaj

13. Romanian Parliament. (2017, 07 25). Law no. 192/2017 for the amendment of Law no. 88/2016 on the establishment of additional mandatory measures for the labeling of fresh milk for consumption and dairy products. Monittorul Oficial, 583. 